\title{
Promoting Community in Early Childhood Programs: A Comparison of Two Programs
}

\author{
James P. Comer • Michael Ben-Avie
}

Published online: 20 April 2010

(c) The Author(s) 2010. This article is published with open access at Springerlink.com

\begin{abstract}
Every interaction within an early childhood program either promotes community or disrupts it. Therefore, excellent early childhood programs have in place a process that pulls the energies and abilities of all the members of the school community together so that everyone-children, educators, parents, and community members-develop well. In particular, healthy interactions between educators and families create the necessary conditions for the early childhood programs: (1) to impact the lifepaths of the families; and, in turn, (2) to engage the families in the work of improving the early childhood programs. In this article, research on the Jewish Early Childhood Education Initiative (JECEI) is presented. JECEI was selected for study because JECEI early childhood programs are characterized by healthy relationships, the capacity to successfully promote children's learning and development, and the engagement of families in the work of school improvement.
\end{abstract}

Keywords Learning and development - Early childhood education - Family engagement - School community · Jewish early childhood education (JECEI) - Jewish life · School improvement process

\section{Introduction}

When we began our work of living in schools in 1968 and helping them to promote child development as the foundational science of education, our focus on child development applied almost exclusively to children. However,

J. P. Comer · M. Ben-Avie ( $\square)$

Yale Child Study Center, New Haven, CT, USA

e-mail: michael.ben-avie@yale.edu as we worked with school communities across the country, we came to realize that adult development and organizational growth were necessary and beneficial to the adults, and critically related to child development. Within our Yale School Development Program, we use the metaphor of six developmental domains as a framework for decision making. These six developmental domains characterize the lines along which children grow-physical, cognitive, psychological, language, social, and ethical. For children to develop well along these domains, they need to identify with others, develop their own identity, and internalize a set of values. Hence our attention to the process by which families, educators, and children can work together as a community and learn together. To see this process in action, an investigation was conducted among families affiliated with the Jewish Early Childhood Education Initiative (JECEI), a transformative change effort for early childhood centers. The research that we present in this article demonstrates why engaging families impacts not only the lifepaths of the children and families, but also the well-functioning of early childhood centers. We wanted to know what are the necessary conditions for enhancing families' sense of meaning and purpose in life as a prelude to engaging them in the work of improving the programs.

\section{Problem Statement}

Family engagement is usually considered in terms of negotiating conflicts between home and school; frequent two-way communication; parents' participation in program decisions about their own children's care and education; the sensitivity of educators as they respond to parental choices and goals; sharing of information; engaging 
parents in the planning for their own children; and linking families to services (Copple and Bredekamp 2009, p. 23). By way of contrast, the research study presented in this article explored quality in early childhood education, the impact of early childhood programs on the lifepaths of the families, and the subsequent contribution of the families to the programs. Through implementing an educational change initiative, a shift occurred among the families and they became concerned for improving the learning and developmental outcomes of all the children, and not only their own children. As a result of this shift, families engaged in the work of improving such aspects of early childhood education as the knowledge level of the educators and the overall functioning of the programs. Moreover, the change process that the programs implemented enabled the school communities to coordinate all the initiatives bombarding them, many with conflicting mandates. This transformative, whole school change process was far more effective in impacting the lifepaths of the families than a similar educational change initiative which focused on only one aspect of the school community, the educators. To promote community in early childhood programs, promote the learning and development of all those who touch the lives of the children.

\section{Quality and Family Engagement}

Quality and family engagement are a combination that effectively promotes children's learning and development. Shonkoff and Phillips (2000) state, "The positive relation between childcare quality and virtually every facet of children's development that has been studied is one of the most consistent findings in developmental science" (p. 313). Moreover, a 2008 Rand report observes that "there is a growing recognition in the early childhood-policy field that the child development benefits of early childhood services are tied to the quality of those services" (p. 19); this statement was based on the work of the Center on the Developing Child at Harvard, the National Forum on Early Childhood Program Evaluation, and the National Scientific Council on the Developing Child. However, the School of the Twenty-First Century, initiated by our Yale colleague Edward Zigler, has long lamented that every study on the quality of child care nationally has found consistently dismal results (Stern and Finn-Stevenson 1999, p. 68). In the United States, the quality of early childhood programs is losing ground. As Copple and Bredekamp (2009) state, "As for teachers, the nation continues to struggle to develop and maintain a qualified teaching force. This difficulty is especially acute in the underfunded early childhood arena... which is losing well prepared teaching staff and administrators at an alarming rate" (p. 2).
The key factor in improving the level of excellence of early childhood programs is increasing the effectiveness of their underlying "operating system." The operating system refers to the team approach to whole school reform that pulls together the energies and abilities of the school community in behalf of the learning and development of children and adults. Promoting both children's learning and development is essential. In their description of the key messages of the National Association for the Education of Young Children's (NAEYC) position statement, Copple and Bredekamp (2009) explain that “All the domains of children's development and learning interrelate. For example, because social factors strongly influence cognitive development, and academic competence-and the cognitive domain influences the social domain-teachers must foster learning and development in both, as well as in the emotional and physical domains" (p. xiii). This statement reflects the core of our work in schools since the establishment of our Yale School Development Program over 40 years ago. We have long advocated that child development should be the foundational science of education because children who develop well, learn well (Comer 1980).

The experiences of our Yale School Development Program in transforming low-functioning schools into great schools across the country are informative (Comer et al. 2004) for early childhood programs that desire to change their operating systems. In well-functioning schools, teams established by the school community come together to resolve long-term problems and engage in global planning that leads to improved learning and developmental outcomes for children. A culture of shared accountability permeates the school community; thus, teams feel safe to take risks trying out new ideas. More than this, our schools impact the lifepaths of children, families, educators and all else who have a stake in the life success of the children. Families who have been influenced by the school community, in turn, find manifold ways to improve the operating system of the schools.

To see how this applies to early childhood education, consider the following series of events that occurred at an early childhood program affiliated with JECEI. JECEI is informed by the scientific study of child development, Jewish thought, the approach of Reggio Emilia schools, and research on the most effective way to engage children and their families in Jewish life. The events took place at a JECEI early childhood program in New York's Stephen Wise Free Synagogue.

The JECEI Leadership Team, comprised of parents, educators, community members, and professionals from the synagogue, guides the JECEI process in actualizing Jewish learning and living for both the educators and families. The team meets monthly to identify core concepts that align with the school's vision. This year, the school has 
embraced the core values of welcoming, gathering, and community building. Each time the JECEI Leadership Team meets, they reflect on past experiences and think together about designing and planning events that support the core values.

Over the summer, a member of the JECEI Leadership Team who is a parent in the school (and a synagogue member), proposed an idea that families, educators, and children build the Sukkah. For the week-long Jewish festival of Sukkot, which occurs in the fall, Jews build temporary structures to recall the temporary structures that the Israelites lived in during the years in the desert. Sukkot is also a harvest festival; hence branches and boughs of leafy trees are placed on the top of the temporary structure. Until the JECEI Leadership Team proposed building the Sukkah, the synagogue custodian had built it without engaging the children, educators, and families in the process. The parent envisioned this project as engaging the family in Jewish life, bringing together a community of educators and families, and providing the opportunity for adults and children to participate in Jewish learning.

It is worthwhile to widen the frame for a moment to understand the importance of bringing educators into educational programs about Jewish living and learning. Finding professionals who are trained in early childhood development, skilled in current best practice, and who are knowledgeable about Jewish customs, practices, and traditions is extremely difficult-especially in smaller Jewish communities. Studies on educators in Jewish early childhood education (Vogelstein and Kaplan 2002; Gamoran et al. 1998) noted the lack of educators' professional training in Judaica. In-service training, while available to most early childhood professionals, was inadequate for addressing sustained change initiatives.

In the design phase, the JECEI Leadership Team developed ways in which the educators, families, and children could learn from the "hands-on" tasks. For example, the team considered how the children could participate in the building of the wooden Sukkah. Thus, it was planned that the children would help sand wood and practice using hammers and nails. Children and families were encouraged to decorate the Sukkah on 2 weekday afternoons. A Sukkah-decorating event was held with the JECEI families, the families affiliated with the synagogue's religious school, and the educators. The families and educators collected natural objects to use for decoration and came together as a community.

The families planned a study session after the Sukkah building was completed. One of the fathers volunteered to facilitate the learning and spent time learning with the senior Rabbi to plan the session. The session could have been geared only to the parents. Consistent with JECEI's approach, however, the aim was to deepen the knowledge of the educators as well as the families. As we say, It's all about relationships. Healthy relationships on all levels of the school community create the necessary conditions for improving the functioning of school communities. Thus, the families which organized the study session contributed to improving the early childhood program.

At the meeting following the Sukkah project, the JECEI Leadership Team focused on continuing the values of welcoming and community building. Parents volunteered to plan and organize Sabbath dinners in people's homes. Invitations were extended to all educators as well. Some families volunteered to host the dinner. All families were extended personal invitations from other parents to sign up for the dinners. Families were matched based on the ages of the children, not on pre-existing friendships. Parents also created Sabbath learning materials for the families and educators. Thus, strong relationships were formed among the educators and families due to the initiatives of the families. The newly strengthened relationships proved beneficial when the families, educators, and administrators came together to deepen the implementation- of JECEI's process for improving the operating system of early childhood programs. Again, the operating system refers to how well the program functions in fulfilling the learning and developmental outcomes of the children and the adults in their lives.

JECEI promotes excellence in early childhood programs by helping school communities organize themselves into teams that work to improve the overall excellence of the programs. For example, the JECEI Leadership Team mentioned above is the umbrella team that coordinates all the energies of the educators, families, and the professionals of the host institutions (e.g., the Jewish Community Center in which the early childhood program is housed). The Jewish Life and Learning Team is comprised of professionals and families that plans and implements Jewish living and learning programs. A third team is the Shared Leadership Team which structures collaborative thinking and shared decision making between the director and the educators.

As a national organization, JECEI promotes well-functioning operating systems in affiliated early childhood programs by

- Providing on-site consultative support to JECEI schools and communities;

- Providing an interactive website for JECEI schools, communities, and families;

- Conducting retreats for educators working in Jewish early childhood education and lay leaders;

- Developing Jewish life-long learning programs for children, families, and educators;

- Developing an accreditation process to complement NAEYC accreditation and the equivalent; and 
- Conducting research and evaluation to determine if outcomes are achieved, to improve the delivery of services, and to refine the model.

The Jewish early childhood education initiative (JECEI) has identified five principles of excellence: relationships, vision, learning community, shared leadership, and environment. Each principle of excellence is further defined by sets of indicators. Consider, for example, relationships. In American education, many families interact with early childhood programs only when there is a pressing need with their own children. By way of contrast, JECEI helps early childhood programs engage families on behalf of all the children. Under the principle of excellence for environment, the following indicator appears: "The school building includes space for families to build relationships with one another." JECEI early childhood programs engage the educators in learning about childhood education-including how to work with families. JECEI aims to transform Jewish early childhood centers into Jewish family life centers that ignite a desire and commitment in families to continue Jewish learning and living beyond the early childhood experience. The key question is whether JECEI positively increases families' sense of meaning and purpose by enhancing their connections to Jewish life as a prelude to engaging them in the work of improving the programs.

\section{Predictors of Families' Level of Engagement in Jewish Life Subsequent to Enrolling Their Children in Jewish Early Childhood Education}

For the study, families $(n=1,159)$ rated the impact that the early childhood programs had on their engagement in Jewish life. Engagement was measured by actions (e.g., participating in parenting and adult Jewish education, reading Jewish books or singing Jewish songs, socializing with other Jewish families). Families also indicated the level of influence the programs had in encouraging them to promote social justice, to feel like a link in the chain of the Jewish people from the far past into the future, and to develop a strong sense of meaning in their lives.

The families enrolled their children in programs that were affiliated with either JECEI or Project Kavod II, a comparable early childhood reform initiative that focuses on the work conditions of Jewish early childhood educators. The online parent inventory was administered at 7 JECEI programs (which had a response rate representing $79 \%$ of the families) and at 7 Project Kavod II programs (which had a response rate representing 69\% of the families). The parent inventory was based, in part, on an inventory that we developed to explore the impact of schools on the lifepaths of families.

At the core of the parent inventory were 90 items that addressed all aspects of Jewish early childhood education. The parents were asked to indicate their level of agreement with these items. There is a way to see whether factors emerge from the responses of the families to these items by conducting a statistical procedure known as Principal Component Factor Analysis. An additional analysis, Internal Consistency Reliability Analysis, confirmed that these factors were reliable and, therefore, could be used in further analyses. The five factors which emerged are described in Table 1 along with their reliabilities.

Which factors predict the families' engagement in Jewish life after enrolling their children in Jewish early childhood education? Since the most desired outcome is that the families increase their engagement in Jewish life subsequent to enrolling their children in Jewish early childhood education, the factor that measures their Jewish connections after enrollment is the dependent variable (that which we are trying to predict). Of course, the families'

Table 1 The five factors

\begin{tabular}{|c|c|c|}
\hline Factor & Description & Alpha \\
\hline Selection Criteria & $\begin{array}{l}\text { The considerations the families had when they made their original decision to enroll their children in } \\
\text { Jewish early childhood education, including both secular and religious reasons. }\end{array}$ & .763 \\
\hline Preparedness & $\begin{array}{l}\text { The extent to which the school community is prepared to promote the school community's values (that is, } \\
\text { a strong relationship to the Jewish people), including the educators' demonstration of high levels of } \\
\text { knowledge of Judaism and preparedness to deepen the Jewish learning of the children. }\end{array}$ & .938 \\
\hline Level of Excellence & $\begin{array}{l}\text { The quality rating that the families assign to the underlying operating system of the early childhood } \\
\text { programs. The underlying operating system refers to how well programs function in fulfilling the } \\
\text { learning and developmental outcomes of the children and the adults in their lives. }\end{array}$ & .843 \\
\hline $\begin{array}{l}\text { Prior Engagement of } \\
\text { Families in Jewish Life }\end{array}$ & $\begin{array}{l}\text { The families' engagement in Jewish life PRIOR to enrolling their children in Jewish early childhood } \\
\text { education. Engagement in a religious group is defined in terms of thoughts, emotions, actions, and ways } \\
\text { of partaking of community. }\end{array}$ & .843 \\
\hline $\begin{array}{l}\text { Impact on Families' } \\
\text { Engagement in Jewish life }\end{array}$ & $\begin{array}{l}\text { The families' engagement in Jewish life AFTER enrolling their children in Jewish early childhood } \\
\text { education. }\end{array}$ & .817 \\
\hline
\end{tabular}


Table 2 The most important predictors of the families' engagement in Jewish life

\begin{tabular}{lll}
\hline Variables & $\begin{array}{l}\text { Adjusted } R \\
\text { square }\end{array}$ & Significance \\
\hline Level of excellence & .478 & $<.0001$ \\
$\begin{array}{l}\text { Prior engagement of families } \\
\text { in Jewish life }\end{array}$ & .497 & $<.0001$ \\
\hline
\end{tabular}

Dependent variable $=$ Impact on families' engagement in Jewish life $N=1,159$

engagement in Jewish life prior to enrolling their children in Jewish early childhood education would most likely be an important predictor of their engagement level afterwards.

An analysis was conducted ("regression") to see which factors would predict the families' subsequent level of engagement. Only two were found to be important predictors: One predictor is not surprising: the families' prior level of engagement in Jewish life. The other important predictor was the families' ratings of the level of excellence of the programs' underlying operating systems (Table 2).

When considering which early childhood program to send their children, the families' priorities were the quality of the educators and the degree to which the programs promoted their children's learning and development, especially a sense of competence in their abilities and strong social skills. Jewish areas of learning and development were not included in the families' list of priorities. Yet, the families' engagement in Jewish life increased over time. The most important predictor of families' subsequent engagement in Jewish life were the ratings of the program's underlying operating system. In other words, if we know the families' ratings of how well the programs function, then we are able to predict how much the programs will influence the families' Jewish connectednessor not.

\section{Level of Excellence in Promoting the Most Desired Developmental Outcomes}

Again, the "underlying operating system" refers to how well programs function in fulfilling the learning and developmental outcomes of the children and the adults in their lives. Consider our work with dysfunctional schools that serve urban, minority youth placed at risk. Our most desired developmental outcome is "whole child" development. As we explain in Ben-Avie et al. (2003):

Students' development may be balanced, constrained, or uneven depending on the way students understand their experiences. In optimal circumstances, that understanding is guided by skilled and caring adults who are available and accessible at critical moments. Development is usually constrained when the student has physical or psychological needs that aren't met. When development is uneven, there is an overemphasis on one aspect of development to the detriment of overall development in the present and, possibly, in the future. To illustrate the latter, if students' cognitive development has been overemphasized to the detriment of their social development, they may be at grade level in their learning of math and science, but may be unable to successfully engage in teamwork and group problem-solving, which may ultimately impact their success at higher levels of mathematics. (p. 12)

The aim of education, therefore, is to provide youth with developmental experiences that help them develop some sense of where they're going, what they want for themselves, their responsibility to other people, and their responsibilities to the larger society. Learning the formulas and procedures of the mathematics and sciences is essential, but knowing only formulas and procedures will not help the young make sense of our rapidly changing world. They need an education that will enable them to handle technology, the sciences, and all the contradictions that are involved in the social world - to empathize with and care about people who are not as successful as they are. Today's students need an education that trains them to assess, decide, and act in ways that are good for themselves and society-and this requires that their teachers continuously demonstrate their knowledge not only of math and science but also of social and emotional development (ibid, p. 10).

The most desired developmental outcome in Jewish education is to promote the children's relationship with the Jewish people-past, present, and future. Developmental outcomes of the process of forging a strong relationship with a religious community are framed in terms of thoughts, emotions, actions, and partaking of community (especially through language). The research question, therefore, is about JECEI's level of excellence and preparedness to promote this aspect of development among the families, educators, and ultimately the children-in comparison with a similar educational change initiative.

As mentioned earlier, the inventory was administered to families who enrolled their children in Jewish early childhood programs that were affiliated with either JECEI or Project Kavod II; these are two similar Jewish early childhood educational initiatives. The educational approach of the two initiatives were comparable as well as the expertise in change management. In fact, many of the same professionals were involved in both initiatives. For 
Table 3 The impact of the Jewish early childood programs on families' Jewish life: selected instances in which the JECEI families scored higher than the Project Kavod II families

"The Jewish early childhood program has influenced our family by..."

\begin{tabular}{lllr}
\hline Variable & Mean(SD) JECEI & Mean(SD) Project Kavod II & 2-tail significance \\
\hline Assisting us in our parenting skills & $3.62(.936)$ & $3.39(.876)$ & $<.001$ \\
Engaging parents in discussions about Jewish life & $3.69(1.027)$ & $3.51(1.029)$ & .013 \\
Encouraging us to be good people & $3.78(.834)$ & $3.57(.825)$ & $<.001$ \\
Encouraging us to promote social justice & $3.60(.883)$ & $3.42(.837)$ & $<.001$ \\
Leading us to experience joy in Jewish life & $4.01(.732)$ & $3.88(.785)$ & .017 \\
\hline
\end{tabular}

$n$ of Project Kavod II (Jewish families only) $=297$

$n$ of JECEI (Jewish families only) $=537$

Table 4 JECEI had higher scores on items that measure Preparedness

\begin{tabular}{|c|c|c|c|}
\hline Variable & Mean(SD) JECEI & $\begin{array}{l}\text { Mean(SD) Project } \\
\text { Kavod II }\end{array}$ & $\begin{array}{l}\text { 2-tail } \\
\text { significance }\end{array}$ \\
\hline Quality of Jewish life programming & $1.93(.870)$ & $1.76(.827)$ & $<.001$ \\
\hline The program does a good job of teaching children about Jewish life. & $1.47(.705)$ & $1.35(.603)$ & $<.001$ \\
\hline The program provides an excellent Jewish education. & $1.55(.661)$ & $1.49(.710)$ & $<.001$ \\
\hline The educators are well-prepared to deepen the Jewish learning of the children & $4.22(.797)$ & $4.07(.785)$ & $<.001$ \\
\hline The educators are engaging parents in discussions about Jewish life & $3.68(1.020)$ & $3.54(.996)$ & .022 \\
\hline The educators are fostering a love of Judaism. & $4.33(.676)$ & $4.09(.743)$ & $<.001$ \\
\hline
\end{tabular}

$n$ of Project Kavod II (Jewish families only) $=297$

$n$ of JECEI (Jewish families only) $=537$

example, the Project Kavod Director is now the program officer responsible for JECEI at The Steinhardt Foundation. Project Kavod's change consultant became JECEI's executive director.

The JECEI families' had scores that were higher than those of the Project Kavod II families on the factor known as Impact on Families' Level of Engagement, and the differences were not due to chance $(p=.006)$. Table 3 shows examples of the impact of the Jewish early childhood programs on families' engagement in Jewish life after enrolling their children.

\section{Attributing Positive Change to JECEI}

In order to attribute, at least in part, the JECEI families' higher scores on the Impact on Families' Level of Engagement factor to JECEI's process, evidence is needed that demonstrates that JECEI programs operated at a higher level in terms of the quality of their preparedness to promote strong relationships to the Jewish people. Indeed, this is the case. The JECEI families had higher ratings of the factor known as Preparedness ("The extent to which the school community is prepared to promote the school community's values"), and the differences were statistically significant (see Table 4).

Moreover, when comparing the scores of the JECEI families with the scores of the Project Kavod II families, the JECEI families had a significantly higher frequency of participation in parent education since enrolling their children as well as greater participation in adult Jewish education (see Table 5).

Not only did the JECEI families engage in parenting programs at a higher rate, they also engaged in adult Jewish learning at a higher rate. The take-home message is that the JECEI families initiated adult Jewish educational programs for the educators as well as the families. Again, one of the most salient challenges of Jewish early childhood education is the lack of Judaic knowledge among the educators. By organizing adult Jewish educational programs that

Table 5 The scores of the JECEI families' participation in learning were higher than those of the Project Kavod II families, and the differences were not due to chance

\begin{tabular}{llll}
\hline Variable & $\begin{array}{l}\text { Mean(SD) } \\
\text { JECEI }\end{array}$ & $\begin{array}{l}\text { Mean(SD) } \\
\text { Project Kavod II }\end{array}$ & $\begin{array}{l}\text { 2-tail } \\
\text { significance }\end{array}$ \\
\hline Parenting programs & $1.40(.491)$ & $1.16(1.40)$ & $<.001$ \\
Adult Jewish learning & $1.25(.434)$ & $1.07(.250)$ & $<.001$ \\
\hline
\end{tabular}


include the educators, the families contribute to raising the preparedness of the educators and, thereby, the quality of the early childhood programs.

Consider, for example, the learning circles that take place at a JECEI early childhood program located in the Jewish Community Center of Manhattan. This is a series of small-group and large-group adult Jewish learning sessions that take place in people's homes and, for the large-group sessions, at the Jewish Community Center. The facilitators, who are parents, and an educator personally invite the parents and educators to participate. A group of volunteers comprised of families and educators meet together with the head of school to choose the topics for discussion that would be of particular interest to parents and educators (for example, on promoting the learning and development among young Jewish children), to study the texts before the small group sessions, and reconvene to debrief following the small group sessions. The learning circles are so compelling that alumni families have requested to continue their involvement in the program even after their children have transitioned to Kindergarten. More than this, the strong relationships that were formed between families and educators resulted in change not only in the early childhood program, but also in the community.

As a result of these improved relationships, changes have emerged impacting the families, the early childhood program, and the Jewish Community Center. Families have formed friendships that make them feel more connected to one another and they have deepened their sense of belonging to the Jewish community. The overall quality of the early childhood program has increased because families became involved in the leadership of the program and brought their time and professional experiences to the JECEI teams. More than this, implementation of JECEI has led the entire Jewish Community Center-and not just the early childhood program - to reexamine how the professionals and lay leaders relate to the members, the programming provided, and how those programs are delivered. A far stronger community is emerging.

\section{Implications}

Excellent early childhood programs have in place a process that pulls the energies and abilities of all the members of the school community together so that everyone-children, educators, parents, and community members-develop well. In this article, the outcomes of two early childhood initiatives were compared: Project Kavod II primarily focused on the work conditions of the educators. JECEI implemented a governance and management process that improved relationships and thereby increased the capacity of the early childhood centers to impact the families. Early childhood programs and schools try to implement ambitious reform initiatives by focusing on pieces-working conditions, curricular initiatives, family engagement, hallway art, special events, professional development. What is needed is a governance and management process that enables the school community to anticipate and manage change as well as coordinate all the initiatives bombarding the early childhood program. With this process, family engagement is not merely something nice to do, but rather family engagement is interwoven into the community's plan to achieve the desired learning and developmental outcomes of the children.

Consider the narrative earlier in this article that described the building of the Sukkah. The Sukkah building was initiated by the families, and not the educators. The leadership team sought ways in which the educators, families, and children could learn from the "hands-on" tasks, and not just the children. Because the school community paid attention to relationships within the school community, the educators welcomed the opportunity to learn. Most important, the Sukkah building was not a one-time family involvement project. The project was designed to spark ongoing study sessions to deepen the knowledge of the educators as well as the families. The more the educators and families engaged together in improving the underlying operating system of the early childhood program, the more every day, ordinary interactions helped to promote community. And children need a healthy, well-functioning community in their lives in order to learn and develop well.

\section{Conclusion}

JECEI is a school reform initiative informed by the scientific study of child development, Jewish thought, the approach of Reggio Emilia schools, and research on the most effective way to engage children and their families in Jewish life. JECEI early childhood programs are characterized by healthy relationships, increased capacity to successfully promote children's learning and development, and the engagement of families in the work of school improvement. In comparison to a similar Jewish early childhood educational initiative, JECEI families had statistically significant higher scores on a scale of items that addressed the extent to which the early childhood program influenced the connections of the families to Jewish life: provided them with assistance in enhancing their parenting skills, encouraged them to be good people, encouraged them to promote social justice, encouraged them to respect the potential of each person, helped them feel better about being Jewish, and led them to experience joy in Jewish life. JECEI families also participated in adult Jewish learning at a higher rate that was not due to chance. In turn, JECEI 
early childhood centers developed ways to engage the families in the work to improve the centers. Far stronger communities emerged.

Acknowledgments The authors gratefully acknowledge that JECEI's Irene Lustgarten provided the vignettes that appear in this chapter.

Open Access This article is distributed under the terms of the Creative Commons Attribution Noncommercial License which permits any noncommercial use, distribution, and reproduction in any medium, provided the original author(s) and source are credited.

\section{References}

Ben-Avie, M., Haynes, N. M., White, J., Ensign, J., Steinfeld, T., \& Sartin, L. (2003). Youth development and student learning in math and science. In N. M. Haynes, M. Ben-Avie, \& J. Ensign (Eds.), How social and emotional development add up: Making gains in math and science education (pp. 9-35). New York, NY: Teachers College Press.

Comer, J. P. (1980). School power: Implications of an intervention project. London: Free Press.
Comer, J. P., Joyner, E. T., \& Ben-Avie, M. (2004). Six pathways to healthy child development and academic success. Thousand Oaks, CA: Corwin Press.

Copple, C., \& Bredekamp, S. (2009). Developmentally appropriate practice in early childhood programs serving children from birth through age 8 (3rd ed.). Washington, DC: National Association for the Education of Young Children.

Gamoran, A., Goldring, E., Goodman, R. L., Robinson, B., \& Tammivaara, J. (1998). The teachers report: A portrait of teachers in Jewish schools. Cleveland, $\mathrm{OH}$ : Mandel Foundation.

Rand Report (2008). The economics of early childhood policy: What the dismal science has to say about investing in children (by $\mathrm{M}$. Rebecca Kilburn and Lynn A. Karoly). Retrieved on January 31, 2010 at http://www.rand.org/pubs/occasional_papers/2008/ RAND_OP227.pdf.

Shonkoff, J. P., \& Phillips, D. A. (2000). From neurons to neighborhoods: The science of early childhood development. Washington, DC: National Academy Press.

Stern, B., \& Finn-Stevenson, M. (1999). Preregistered for success: The Comer/Zigler initiative. In J. P. Comer, M. Ben-Avie, N. M. Haynes, \& E. T. Joyner (Eds.), Child by child: The Comer process for change in education (pp. 63-77). NY: Teachers College Press.

Vogelstein, I., \& Kaplan, D. (2002). Untapped potential: The status of Jewish early childhood education in America. Baltimore: Jewish Early Childhood Education Partnership. 